\title{
Turbidity and Other Effects Resulting from Trafalgar Sandbank Dredging and Palmar Beach Nourishment
}

\author{
Jorge Roman-Sierra'; Marina Navarro²; Juan Jose Muñoz-Perez ${ }^{3}$; and Gregorio Gomez-Pina ${ }^{4}$
}

\begin{abstract}
Beach-nourishment requirements on the southwestern Spanish coast have led to a significant increase in offshore dredging. Following a new research line, assessment of changes recorded in physicochemical and biological parameters due to dredging and dumping operations was performed at the Cape of Trafalgar and Palmar Beach during June and July 2008. Turbidity, salinity, pH, dissolved oxygen, temperature, and suspended-sediment data were collected at 10 stations. At the end of the study, a three-campaign monitoring program was implemented for 1 year to assess the possible effects on biological communities and sediment properties. The relevant results, such as the average extent of the sediment plume $(<400 \mathrm{~m})$ and its persistence in the environment $(<10 \mathrm{~min})$, are discussed in this paper. A precise correlation between turbidity and suspended sediments and the recovery time of ecological balance were also established. Furthermore, minimal and reversible effects caused by dredging and dumping operations in this type of marine environment were identified. DOI: 10.1061/(ASCE)WW.1943-5460.0000098. ( 2011 American Society of Civil Engineers.
\end{abstract}

CE Database subject headings: Turbidity; Dredging; Beach nourishment; Parameters; Environmental issues.

Author keywords: Turbidity; Sandbank dredging; Beach nourishment; Physicochemical parameters; Environmental effects; Cape of Trafalgar; Gulf of Cadiz.

\section{Introduction}

The dredging of marine sandbanks has been the usual technique for the nourishment of nearby beaches along the Spanish coast. Beach nourishment has evolved as the favored erosion-mitigation strategy in many areas of the world. The increasing number of people living on the coast, the safety of those people, and the high values of coastal property are all factors that have made beach nourishment a cost-effective strategy for managing erosion in many locations. Dredging has become increasingly inexpensive, and sand quality is often improved as borrow pits are moved closer to the shore (Kennedy et al. 2010). To be cost-effective, the optimum location for a borrow pit must be close enough to shore to minimize transport costs yet far enough offshore to minimize negative effects because of the presence of the dredge pit (Work et al. 2004).

According to Muñoz-Perez et al. (2003), a need for the regeneration of beaches in general exists in Spain because of the erosion experienced by most of the coast, which is attributed to the rise in sea level, the retention of sand in dams, occupation of dry beaches by urbanized areas, the removal of sand as a material for building

\footnotetext{
${ }^{1}$ Applied Physics Dept., Sea Sciences Faculty, Univ. of Cadiz, CASEM, Poligono Rio San Pedro, s/n, 11510 Puerto Real (Cadiz), Spain (corresponding author). E-mail: jorge.roman@uca.es

${ }^{2}$ Applied Physics Dept., Sea Sciences Faculty, Univ. of Cadiz, CASEM, Poligono Rio San Pedro, s/n, 11510 Puerto Real (Cadiz), Spain. E-mail: marina.navarro@uca.es

${ }^{3}$ Applied Physics Dept., Sea Sciences Faculty, Univ. of Cadiz, CASEM, Poligono Rio San Pedro, s/n, 11510 Puerto Real (Cadiz), Spain. E-mail: juanjose.munoz@uca.es

${ }^{4}$ Coastal Dept. Ministry of Environment. C/ Marianista Cubillo, 7, 11008 Cadiz, Spain. E-mail: ggomez@mma.es

Note. This manuscript was submitted on September 2, 2010; approved on April 20, 2011; published online on October 14, 2011. Discussion period open until April 1, 2012; separate discussions must be submitted for individual papers. This paper is part of the Journal of Waterway, Port, Coastal, and Ocean Engineering, Vol. 137, No. 6, November 1, 2011. (c)ASCE, ISSN 0733-950X/2011/6-332-343/\$25.00.
}

construction, and so on. Unfortunately, the lack of sandbanks off the southwestern Spanish coast has been an ongoing problem for beach nourishment, even with the existence of dunes with an excess sand supply (Muñoz-Perez et al. 2009), because of the unprofitable sand-transport costs. This handicap led to the need to find new, alternative sources of sand. These alternatives are sand redistribution on the beach, the use of sand quarries, and the dredging of marine harbors, river mouths, and other marine sandbanks increasingly distant from the coastline. Today, this is possible because current dredges have a greater capacity for dredging at high depths, up to $100 \mathrm{~m}$ (Muñoz-Perez et al. 2003). In this context, dredging and material disposal could be defined as an artificially induced process of erosion, transport, and deposition of sediments. This process has the potential to directly or indirectly produce negative and positive effects on the environment of the dredged and discharge areas and on surrounding areas. Often, legislative and environmental regulations are set to limit the effect of these disturbances, which therefore must be quantified (OSPAR 2003). According to Winterwerp (2002), the level of disturbance depends on the amount of sediments released and the overflow procedure, on the hydrodynamic conditions, and on the near-field conditions. Among other activities, the primary sources of anthropogenic open-water turbidity are generally channel-maintenance dredging, the disposal of dredged material, and beach replenishment.

Many studies have been conducted in North America by the U.S. Army Corps of Engineers (USACE) (USACE and USEPA 1992) on maintenance dredging and disposal activities in enclosed waters such as estuaries and embayments, locations where the presence of a high fine-sediment fraction contributes to elevated turbidity. Turbidity is the most important physical change generated in water quality (Goodwin and Micaelis 1984). With dredging, there may be potential problems associated with sediment plumes such as alterations in water quality of the local environment, both in the dredging and dumping areas (Drucker et al. 2004; Hitchcock and Bell 2004). According to Barnard (1978), tides also affect plume dispersion, with plumes extending landward and seaward during 
the incoming flood tides and the outgoing ebb tides, respectively. In many cases, increases in suspended-sediment concentration (SSC) levels are less than those generated by commercial shipping operations or during severe storms. Storms, floods, and large tides can increase SSC over much larger areas and for longer periods than dredging operations. Therefore, it is very difficult to distinguish between dredging-induced turbidity and that generated by natural marine processes or normal navigation activity (Pennekamp et al. 1996). Hitchcock et al. (1999) cited numerous dredging-related plume studies from around the world in their report on benthic and surface plumes prepared for the U.S. Minerals Management Service. Both surface and benthic plumes are usually associated with marine disposal of dredged material (open-water pipeline discharges or hopper-dredge releases). Other authors have identified potential effects of turbidity on water quality and organisms in inland bays and estuaries worldwide (Long et al. 1996; Brenon and Le Hir 1999; Robinson et al. 2005). Aquatic systems are very diverse, dynamic, and changing in time and space. Physical and chemical changes may be produced during and after dredging and dumping of the dredged material (Herbich 1992). The reported effects include increased turbidity, the reduction of primary productivity, and changes in the structural characteristics of plant communities (Lewis et al. 2001). In this context, several studies have been conducted elsewhere to determine dredging effects on aquatic flora such as seagrasses (Onuf 1994; Long et al. 1996), seaweeds (Lyngby and Mortensen 1996), and phytoplankton (Iannuzzi et al. 1996). Nevertheless, a review of the pertinent literature indicates a scarcity of existing data concerning the biological responses of fish and shellfish to suspended-sediment dosages commonly associated with dredging projects (Wilber and Clarke 2001). According to Winterwerp (2002), the bulk behavior of a water-sediment mixture appears to be of greater importance than the settling velocity of individual sediment particles. Several in situ case studies of this behavior have been reported in the open literature (Teeter 1988; Wolanski et al. 1992). Most of the studies, however, are either confidential or have been published in reports poorly accessible to interested engineers.

Considerably less research has been conducted in unprotected marine waters, where most of the literature has focused on the effects of turbidity on specific marine species and biosystems or on the transport dynamics of coarse sand rather than on the temporal or spatial characteristics of the resuspension of fine sediment. Few complete studies have been undertaken to quantify turbidity conditions during beach-nourishment activities (CSMW 2004). The methodology presents a detailed procedure for multidisciplinary environmental studies about the effect of marine dredging and dumping activities. The application of these steps to one case and its interpretation constitute the novel aspects of the present work. Therefore, the main goal of this work is the identification of possible alterations in the physicochemical and biological parameters of unprotected marine waters off the southwestern coast of Spain by using this methodology. Studies were performed during a sandbank dredging project for beach nourishment over the months of June and July 2008.

\section{Antecedents}

The coastline of the Gulf of Cadiz has been in recession for at least the past century. Erosion is caused by a negative sediment budget because of the instability of eroded coastal cliff sediments (Anfuso and Gracia 2005). Analysis of field data and aerial photographs over the past half-century period show that the coastline has suffered a recession rate of approximately $1 \mathrm{~m} /$ year on some points of the Spanish Southwest Atlantic coast (Muñoz-Perez et al. 2001). Because of these erosion rates, the Spanish Coastal Authority of the Ministry of Environment has developed a coastal-protection program based on beach nourishment, sometimes accompanied by supporting breakwater construction (Muñoz-Perez et al. 2001) or the installation of artificial reefs for coastal defense (Muñoz-Perez 2008). Furthermore, sediment-loss values on this coast were calculated per meter and year by dividing the yearly erosion rate by the beach length; the average value was $37.5 \mathrm{~m}^{3} / \mathrm{m} /$ year (MuñozPerez et al. 2001). These high erosion rates justify dredging activities for beach-nourishment purposes. In fact, Muñoz-Perez et al. (2001) found that a substantial decrease in the replenishment sand volumes in successive restorations performed on certain beaches led to drastic reductions in the yearly erosion rates. In this context, the study area, the coast of the Cadiz province, presents a variety of coastal-engineering and coastal-management problems with difficult solutions (Gomez-Pina et al. 2006). Thereby, beach-erosion problems have been solved by adding sand to the beaches along the Gulf of Cadiz.

\section{Study Area}

The study area includes an offshore borrow site, the Meca sandbank, and a dumping coastline zone, Palmar Beach, both located near the Strait of Gibraltar in southwestern Spain. More precisely, both are located to the west of the Cape of Trafalgar $\left(36^{\circ} 12^{\prime} \mathrm{N}\right.$; $\left.6^{\circ} 05^{\prime} \mathrm{W}\right)$ on the continental shelf that extends off the coast of Cadiz (see Fig. 1). In 2008, the spring tidal range was from 0.1 to $2.6 \mathrm{~m}$, in relationship to the hydrographic zero. The average wind velocity was $5.7 \mathrm{~m} / \mathrm{s}$, and the maximum velocity was $18.2 \mathrm{~m} / \mathrm{s}$. The maximum current velocity was $63.3 \mathrm{~cm} / \mathrm{s}$, and the average value was $13 \mathrm{~cm} / \mathrm{s}$. The average wave height was approximately $1.15 \mathrm{~m}$ with a maximum of $9 \mathrm{~m}$ (Fig. 2). All values are obtained from the same deep water buoy: Gulf of Cadiz (Buoy no. 2342) (Spanish Port System 2008).

The Meca sandbank is a triangular submerged shelf found between 15 and $20 \mathrm{~m}$ depth lying $5 \mathrm{~km}$ southwest of Palmar Beach. There are several other irregular formations on the seabed within the study area, such as the reef flat of Conil and the low, rocky

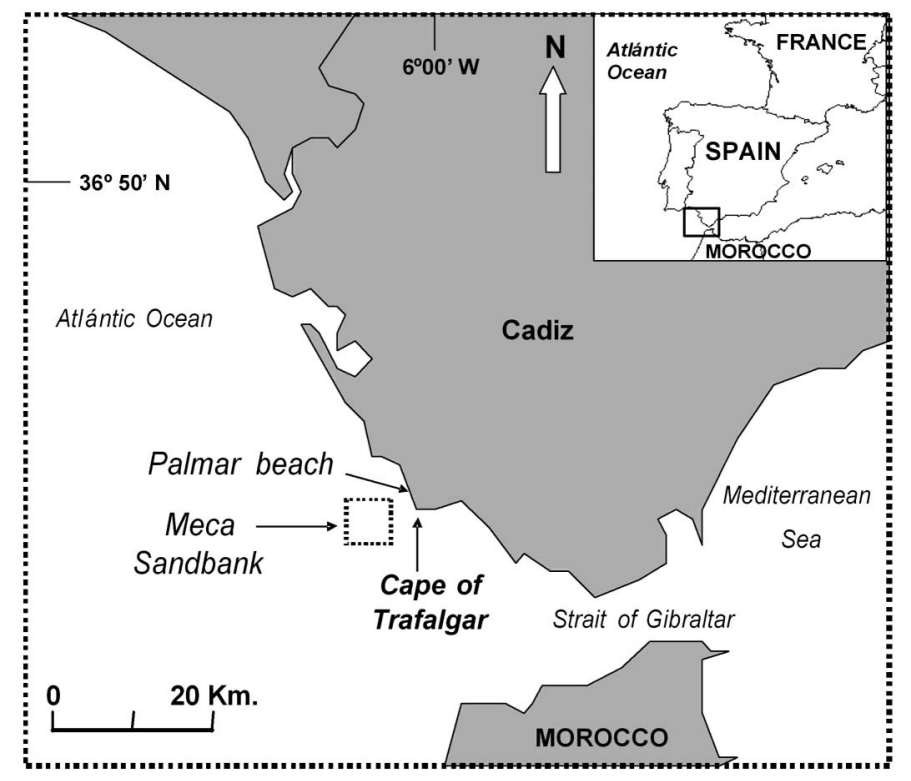

Fig. 1. Location of the study area, including dredging and dumping zones 


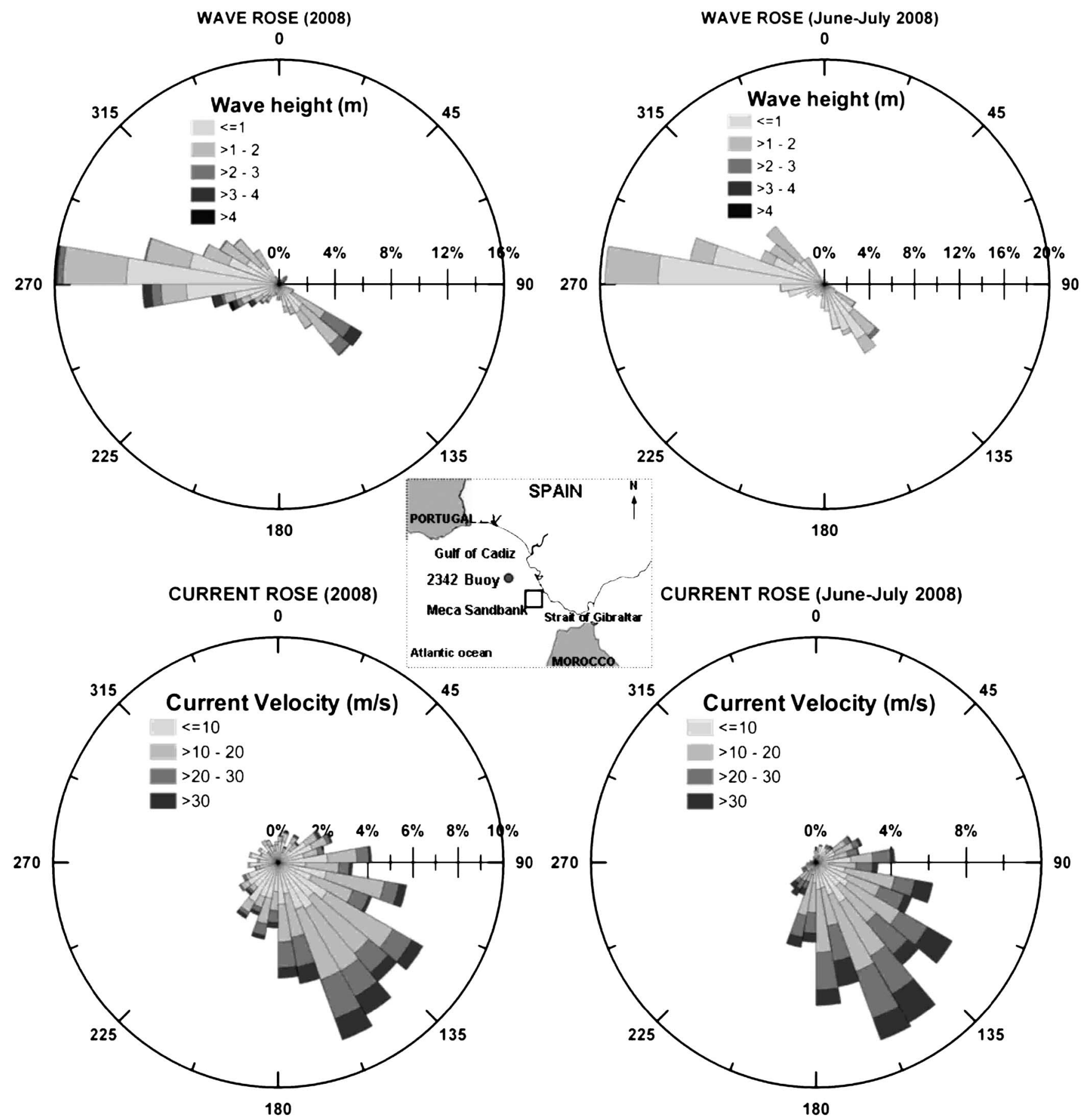

Fig. 2. Wave and current roses in the long-term (2008) and short-term (June to July 2008) [data from Gulf of Cadiz Buoy no. 2342 (Spanish Port System 2008)]

Cape of Trafalgar. Quaternary elements characteristic of the marshes and alluvial deposits appear in the area (Dabrio et al. 2000). The Meca sandbank has a surface area of approximately $2.5 \mathrm{~km}^{2}$ and an estimated usable sand volume of $5,000,000 \mathrm{~m}^{3}$ over the next 10 years. It is thus an important national marine reservoir of medium and coarse sands. This dredging area was selected because historically it has been highly utilized by the Coastal Authority for beach-nourishment purposes. The most important dredging operations on the Meca sandbank in the past decade were for Cadiz and Palmar Beach nourishments $\left(260,000 \mathrm{~m}^{3}\right.$ in 2004 and $595,000 \mathrm{~m}^{3}$ in 2008 , respectively). Currently, the remaining capacity of the sandbank is estimated at approximately
83\%. According to other environmental studies (Ministry of Environment 2003), there was no significant environmental or physical effect to the area because of sand extraction.

\section{Methodology}

Dredging and dumping work was undertaken by using a trailing suction hopper dredge (TSHD). The type and characteristics of the dredge used are detailed in Table 1.

The dredging and beach-nourishment work began in June 2008 and was finished in July 2008, a period of 8 weeks. 
Table 1. Features of the Hydraulic Dredge Used

\begin{tabular}{lc}
\hline Dredger features & \\
\hline Name & HAM-311 \\
Company & Dravo S.A. \\
Type & Trailing suction hopper dredger (TSHD) \\
Year of construction & 1994 \\
Hopper capacity & $3,510 \mathrm{~m}^{3}$ \\
Deadweight & $5,059 \mathrm{tons}$ \\
Speed loaded & $11.5 \mathrm{kn}$ \\
Speed dredging & $3 \mathrm{kn}$ \\
Propulsion & $2 \times 1,150 \mathrm{~kW}$ \\
Bow thruster & $375 \mathrm{~kW}$ \\
Maximum dredging depth & $29.6 \mathrm{~m}$ \\
Suction pipes & $\Phi 900 \mathrm{~mm}$ \\
Discharge pipe & $\Phi 800 \mathrm{~mm}$ \\
Total power installed & $5,317 \mathrm{~kW}$ \\
Inboard dredge pump & $1,545 \mathrm{~kW}$ trailing; $2,820 \mathrm{~kW}$ discharging \\
\hline
\end{tabular}

A preoperational campaign was performed to determine the resulting environmental effects on the Meca sandbank and Palmar Beach. This was useful in determining the water quality of the environment in the absence of dredging work. Afterward, seven campaigns were conducted weekly, developing studies of different physical and chemical parameters in the water column and sediment properties. All field campaigns during the works were developed under similar marine weather conditions because the TSHD cannot operate in waves more than $1.5 \mathrm{~m}$. Finally, after the work was completed, three postoperation campaigns were performed (3,6 and 12 months later) to assess the effects on the environment and sediments.

Ten sampling stations were used in the study area: four sampling stations were established at the dredging zone $(1,000 \times 500 \mathrm{~m})$ and six other stations were located in two profiles in the discharge area at depths of 2, 5, and $10 \mathrm{~m}$ (Fig. 3). All stations were located by means of a differential global-positioning system (DGPS) with a $1-\mathrm{cm}$ precision. The location of monitoring stations was taken into

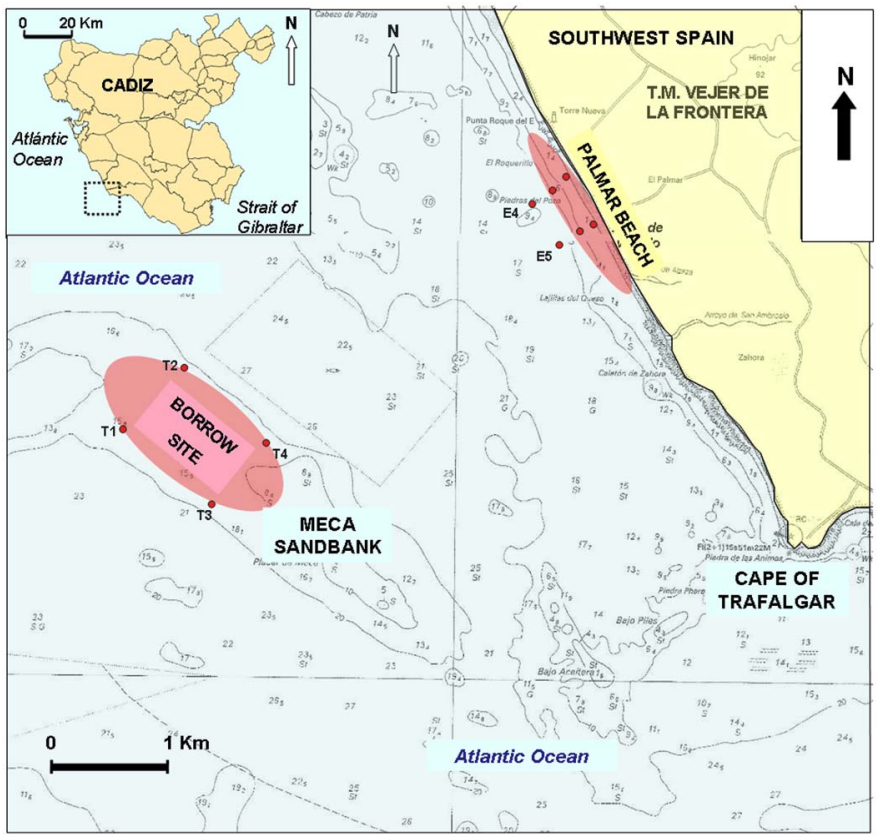

Fig. 3. Locations of dredging (T) and dumping (E) stations account when designing the fieldwork plan. It is evident that the number of sampling stations, the type and frequency of chemical analysis, and the media analyzed are important considerations even for small-scale dredging events (Lewis et al. 2001).

\section{Physicochemical Water Quality}

Several physicochemical water-quality parameters were determined in situ before and during dredging and dumping activities at the aforementioned 10 sampling stations. The following parameters were recorded continuously: turbidity, salinity, $\mathrm{pH}$, dissolved oxygen, temperature, and redox potential. Portable analytical instrumentation was used for these measurements (Hydrolab DS-5X multiparameter); the values were determined throughout the water column at all stations (UNE 1999). This instrumentation has a precision of \pm 0.1 nephelometric turbidity units (NTU) for the turbidity parameter. Water samples were taken in Ruttner and Niskin oceanographic bottles (volume $2 \mathrm{dm}^{3}$ ) and were stored at $4^{\circ} \mathrm{C}$ until use for later chemical analysis. Subsequently, the SSC $(\mathrm{mg} / \mathrm{L})$ was determined in the laboratory by a gravimetric technique (UNE 1999), with a detection limit of $2 \mathrm{mg} / \mathrm{L}$ and a precision of $\pm 1 \mathrm{mg} / \mathrm{L}$.

Furthermore, as a qualitative technique, the turbidity plume was analyzed by using aerial photographs taken from a remotecontrolled zeppelin. This technique permitted demonstration of the expansion and durability of the turbidity plume on the sea surface when the dredging work was finished. Photographs were taken before and during dredging operations. Later, 10 photographs were taken each minute after the operations. Color photographs depicted plumes ranging in length from tens to hundreds of meters.

\section{Marine-Sediment Identification}

Grain size is one of the most important sediment particle properties. Sieve analysis is known to be an essential technique for classifying materials and sedimentary environments. It is, therefore, a widely used methodology in the field of coastal engineering. Grain size is related to the tendency of sediments to remain in suspension (Black and Parry 1999).

Sediment samples were collected at each of the 10 stations before and after operations (3, 6, and 12 months). Sediments were taken from the dredge with a stainless-steel Van Veen grab (surface area: $400 \mathrm{~cm}^{2}$ ), capturing a $\sim 10-\mathrm{cm}$ thickness. Afterward, sediments were analyzed by granulometric and statistical studies in the laboratory. The material was sieved over the range of 2 to $0.075 \mathrm{~mm}$ (i.e., 2-, 1-, 0.5-, 0.355-, 0.250-, 0.125-, and 0.075-mm sieves). Size fractions are indicated in millimeters and phi units. The particlesize distributions and total organic carbon (TOC) contents of the sediments were determined by using techniques described in the ASTM published methods (1992). Graphical distributions were standardized for each sample, and inherent sediment values, such as the median diameter $\left(D_{50}\right)$, were obtained. Additionally, other essential values were calculated for littoral protection against coastal erosion, i.e., the mean grain size $\left(M_{\Phi}\right)$, the $\mathrm{SD}$, the symmetry degree (skewness), and the peakedness degree (kurtosis) according to USACE (2008). These results enabled the calculation of cross-shore and along-shore sediment transport at the beaches along with depth of closure, Dean's profile, Vellinga's profile, and several other parameters useful in coastal engineering.

\section{Benthic-Community Characterization}

Benthic-community characterization was performed both in the dredging area (at the same four monitoring zones: T1, T2, T3, and T4) and in the dumping area bottom (two monitoring zones: E4 and E5) on the biocenosis of calm-water infralittoral, photophilic communities. The aim was to assess ecological evolution 
in the sedimentary and rocky-bottom zones in both study areas. This assessment was undertaken by the identification of several biological indexes, i.e., density, diversity, equitability, dominance, and complexity (Lloyd and Ghelardi 1964).

To perform a comparative study, the same monitoring stations were used in the first preoperational campaign and in the following postoperational campaigns (at 3,6 , and 12 months). A total of 14 biological samples were collected: eight in the dumping area (six in zone E4, a rocky platform, and two in E5, the intertidal sandy zone) and six in the dredging area (in zones T1-T4).

Within the dredging area, a sampling was performed at the sea bottom by using indirect tools, such as the Van Veen grab. Biological samples were sieved by using a 1-mm sieve. Afterward, they were immediately labeled and fixed in a $96 \%$ hexamethylenetetramineneutralized alcohol solution. Several drops of Rose Bengal were added to the formol solution to aid in the identification of living organisms.

The sampling methodology performed in the dumping area consisted of the sampling of $1-\mathrm{m}^{2}$ surface segments to quantify changes in the organismal abundance and distribution. At each station, four subsamples of $0.25 \mathrm{~m}^{2}$ each were taken to perform a taxonomic analysis in the laboratory. Ecological indexes such as the Shannon diversity, dominance, density, and percentage of coverage were calculated. This investigation will be extremely useful in determining the ecological environmental quality and allow for its monitoring.

\section{Results and Discussion}

\section{Hydrological Characterization}

Several physicochemical parameters were determined in all water columns at the 10 sampling stations, preoperationally and during dredging and dumping activities.

In case of the turbidity parameter, it was determined first in natural conditions (the preoperational campaign). Normal turbidity concentrations ranged from 0 to 8 NTU. The maximum value was recorded at middepth $(8$ and $11 \mathrm{~m})$ in the dredging zone and minimum value (1 NTU) at the surface. During this phase, the climatological conditions were a wind velocity $\sim 25 \mathrm{~km} / \mathrm{h}$, an averaged current velocity of only $13 \mathrm{~cm} / \mathrm{s}$, and waves from the west at heights $1 \mathrm{~m}$ (Spanish Port System 2008). Generally, overspill from spillways, screening, and open-water disposal generates a far greater quantity of suspended material and larger plumes than bottom disturbances (CSMW 2004). However, it is difficult, if not impossible, to confidently separate anthropogenic modifications from natural evolution (Giardino et al. 2009).
During the dredging operations, there were seven additional weekly campaigns. All these results showed average values of 1.2 NTU and maximum values of $1.6 \mathrm{NTU}$ at $-7.8 \mathrm{~m}$ depth and 3.2 NTU at the surface. During the seven campaigns, the average values of the meteorological conditions were milder than during the preoperational campaign (wind velocity: 10-24 km/h; wave height: $0.6-0.9 \mathrm{~m}$; and current velocity: $13-40 \mathrm{~cm} / \mathrm{s}$; see Table 2).

In addition to these measurements, a temporal and spatial study was performed on the surface of the dredging zone during the first campaign (Fig. 4). Note that the maximum isolated turbidity values of approximately $3 \mathrm{NTU}$ were identified at 0:00, 1:50, and 5:30 min. Turbidity decreased with time and returned to natural conditions approximately 9 min afterward.

In Port Phillip Bay (a semienclosed tidal embayment) in southeastern Australia, turbidity concentrations in the sediment plume in the first $20 \mathrm{~s}$ after dredging were two to three orders of magnitude higher than in natural concentrations (Black and Parry 1994), and approximately $98 \%$ of the sediment in the plume was redeposited within 30 min at Portarlington (Black and Parry 1999).

In the spatial scale, near the dredging zone $(<50 \mathrm{~m})$ the maximum turbidity value was 3 NTU, with other high values at $140 \mathrm{~m}$ (2.7 NTU) and $230 \mathrm{~m}$ (1.8 NTU). These alternative maximum and minimum values are most likely because of the existence and movement of different plume loops on the fixed measurement station and the existence of a strong current velocity in the surface, around $40 \mathrm{~cm} / \mathrm{s}$. Between 250 and $400 \mathrm{~m}$, far from the dredging zone, turbidity values were normalized and similar to the preoperational campaign ( $0-1$ NTU). The spatial evolution of turbidity was similar to a decreasing polynomial curve. A qualitative assessment of the plume dispersion is shown in the aerial photographic sequence (Fig. 5).

According to the data collected (Fig. 4) and the aerial images taken during and after dredging (Fig. 5), the turbidity plume on the surface had a maximum length of $400 \mathrm{~m}$ and an average persistence of approximately 9 min after dredging activities.

Numerous other observations and models made by the USACE (1992) support the conclusion that dredging plumes are localized and of short duration, with a benthic plume extending 700-730 m downcurrent from the dredge. Similar studies have demonstrated that most dredging-induced turbidity plumes are localized, spreading less than a $1,000 \mathrm{~m}$ from their source; the plumes are short lived, dissipating to restore ambient water quality within several hours after dredging is completed (CSMW 2004). These results are characteristic of both offshore operations and those in enclosed waters. Generally, beach-nourishment projects on high-energy beaches quickly equilibrate with the current wave regime. Finer sediments are promptly winnowed from the nourishment material,

Table 2. Climate Conditions in the Study Area during Preoperational and Operational Campaigns

\begin{tabular}{|c|c|c|c|c|c|c|c|c|}
\hline Campaigns & $\begin{array}{l}\text { Preoperational } \\
\text { (June 5, 2008) }\end{array}$ & $\begin{array}{c}\text { 1st campaign } \\
\text { (June 20, 2008) }\end{array}$ & $\begin{array}{l}\text { 2nd campaign } \\
\text { (June } 25,2008)\end{array}$ & $\begin{array}{l}\text { 3rd campaign } \\
\text { (July 2, 2008) }\end{array}$ & $\begin{array}{l}\text { 4th campaign } \\
\text { (July 9, 2008) }\end{array}$ & $\begin{array}{c}\text { 5th campaign } \\
\text { (July 17, 2008) }\end{array}$ & $\begin{array}{l}\text { 6th campaign } \\
\text { (July } 21,2008)\end{array}$ & $\begin{array}{l}\text { 7th campaign } \\
\text { (July } 31,2008)\end{array}$ \\
\hline $\begin{array}{l}\text { Wind velocity } \\
(\mathrm{km} / \mathrm{h})\end{array}$ & 25.7 & 13.7 & 11.4 & 24.4 & 9.21 & 10.6 & 12.5 & 21,0 \\
\hline Wind direction & NW & SE & SW & NW & W & SE & W & NW \\
\hline Wave height (m) & 1.1 & 0.6 & 0.7 & 0.9 & 0.6 & 0.6 & 0.6 & 0.9 \\
\hline Wave period (s) & 3.7 & 3.7 & 3.9 & 3.4 & 3.7 & 3.6 & 3.4 & 3.5 \\
\hline Wave direction & NW & $\mathrm{S}$ & W & NW & SW & SE & W & NW \\
\hline $\begin{array}{l}\text { Current velocity } \\
(\mathrm{cm} / \mathrm{s})\end{array}$ & 13.0 & 40.2 & 25.1 & 23.3 & 25.4 & 19.2 & 15.3 & 13.2 \\
\hline Current direction & SE & SE & SE & SE & $\mathrm{S}$ & SE & SE & SE \\
\hline
\end{tabular}




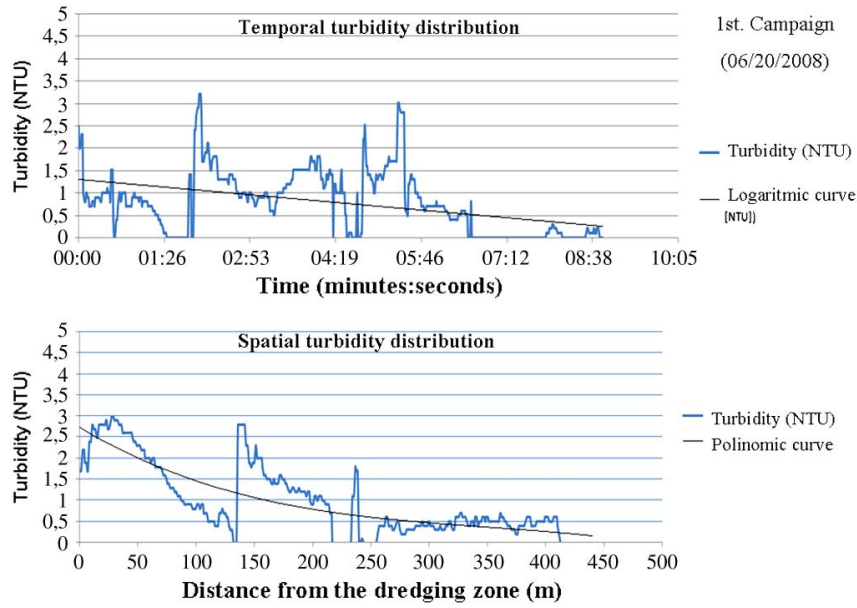

Fig. 4. Temporal and spatial turbidity distributions during the first campaign

causing only a short period of elevated turbidity (Parr et al. 1978). In another study of beach nourishment on North Carolina beaches during 2001 and 2002 (Versar 2004), it was concluded that plumes caused by sand placement and dewatering on the beach face were small, short-lived, and did not create large increases in turbidity over background conditions. Nonetheless, it is generally agreed that turbidity that results from placement of sand on the beach face in beach-nourishment projects is even more localized and transitory than that during offshore or enclosed-water operations. In some studies (Versar 2004), elevated turbidity was rarely observed outside the surf zone and was not discernable from normal turbidity caused by waves in the surf zone. In another study (CSMW 2004), elevated turbidity was limited to a narrow swath in the swash zone in the immediate vicinity of the operation. These results are largely attributable to the use of borrow material that is low in clay and silt and resembles the native beach sand as closely as possible.

In the dumping zone, turbidity values ranged between 0 and 10 NTU in the preoperational stage for all stations and the entire water column. For the following seven operational campaigns, the fixed stations showed that the turbidity had an isolated maximum value of 25 NTU at the surface and average values approximately 3 NTU throughout the water column (Fig. 6).

According to the World Health Organization (WHO 1998) of the European Union, with respect to the quality of potable water intended for human consumption, the turbidity level for surface water must be a maximum of $1.0 \mathrm{NTU}$ at the exit of the watertreatment station. According to Ruffin (1998), the turbidity in a shallow water estuary in the Chesapeake Bay (Maryland) generally ranged from 28 to 121 NTU.

In general, no significant changes from their natural values were detected for the other physicochemical parameters (Table 3).

The averaged dissolved oxygen data show saturation values of approximately $111 \%$ in the dredging and the dumping zones in the preoperational stage for all stations and the entire water column, with SDs of 1.97 and $2.57 \%$, respectively. For the following seven operational campaigns, the average dissolved oxygen values were on the order of $112.5 \%$, with SDs of 0.22 and $0.87 \%$, respectively. Nevertheless, a progressive decrease in dissolved oxygen with depth $(-2 \%)$ was observed in the dredging zone, with constant values in the dumping zone of $\sim 113 \%$.

In the case of redox potential, the average values were very constant in the entire water column, with average data values of approximately $325 \mathrm{mV}$ in the dredging zone and $305 \mathrm{mV}$ in the dumping zone in the preoperational stage for all stations. For the remaining operating campaigns, the mean values were
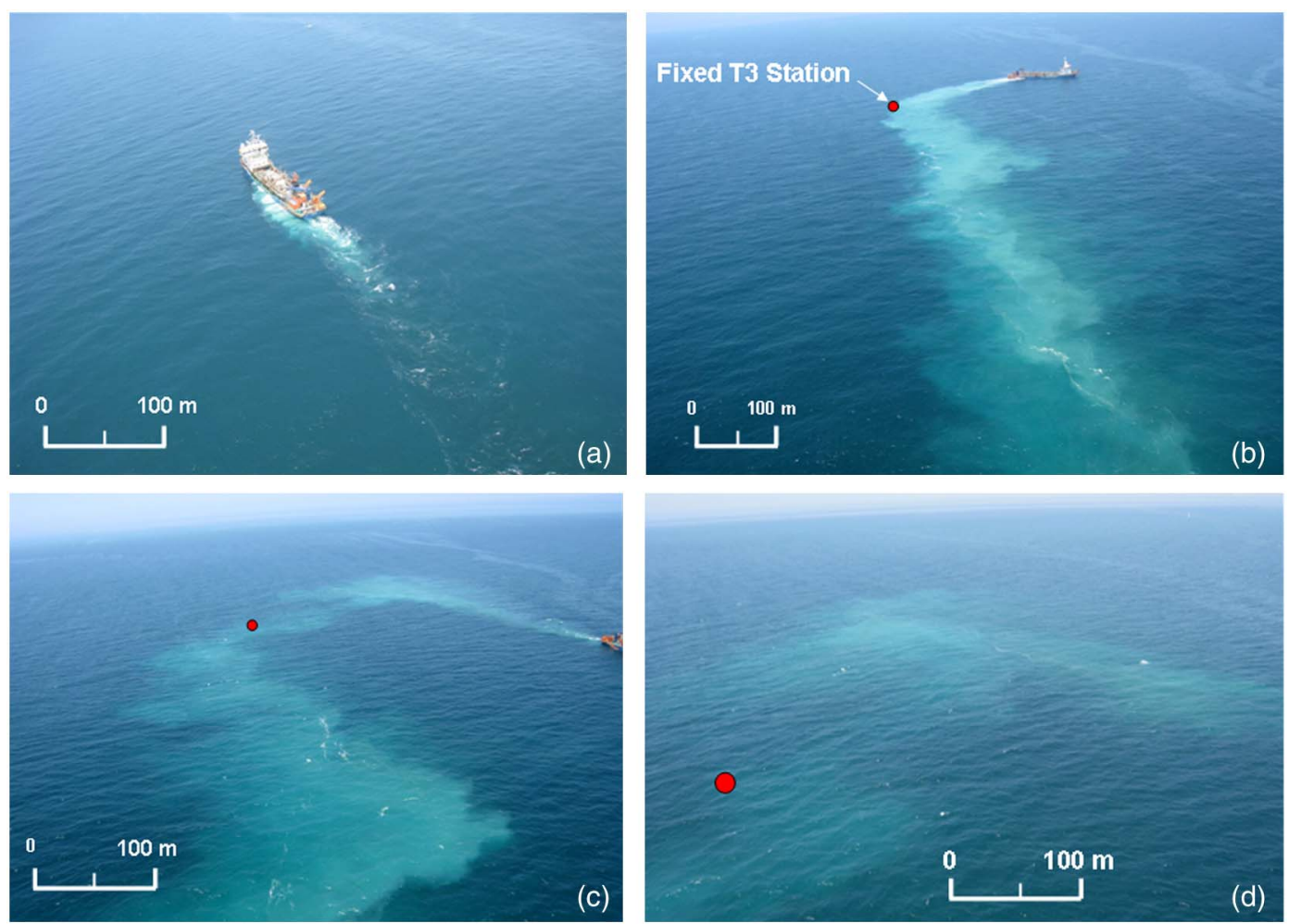

Fig. 5. Aerial photographs of the sediment plume and fixed stations in the Meca sandbank (images by Jorge Roman-Sierra): (a) start of dredging; (b) during dredging activities; (c) end of dredging; (d) after $10 \mathrm{~min}$ 


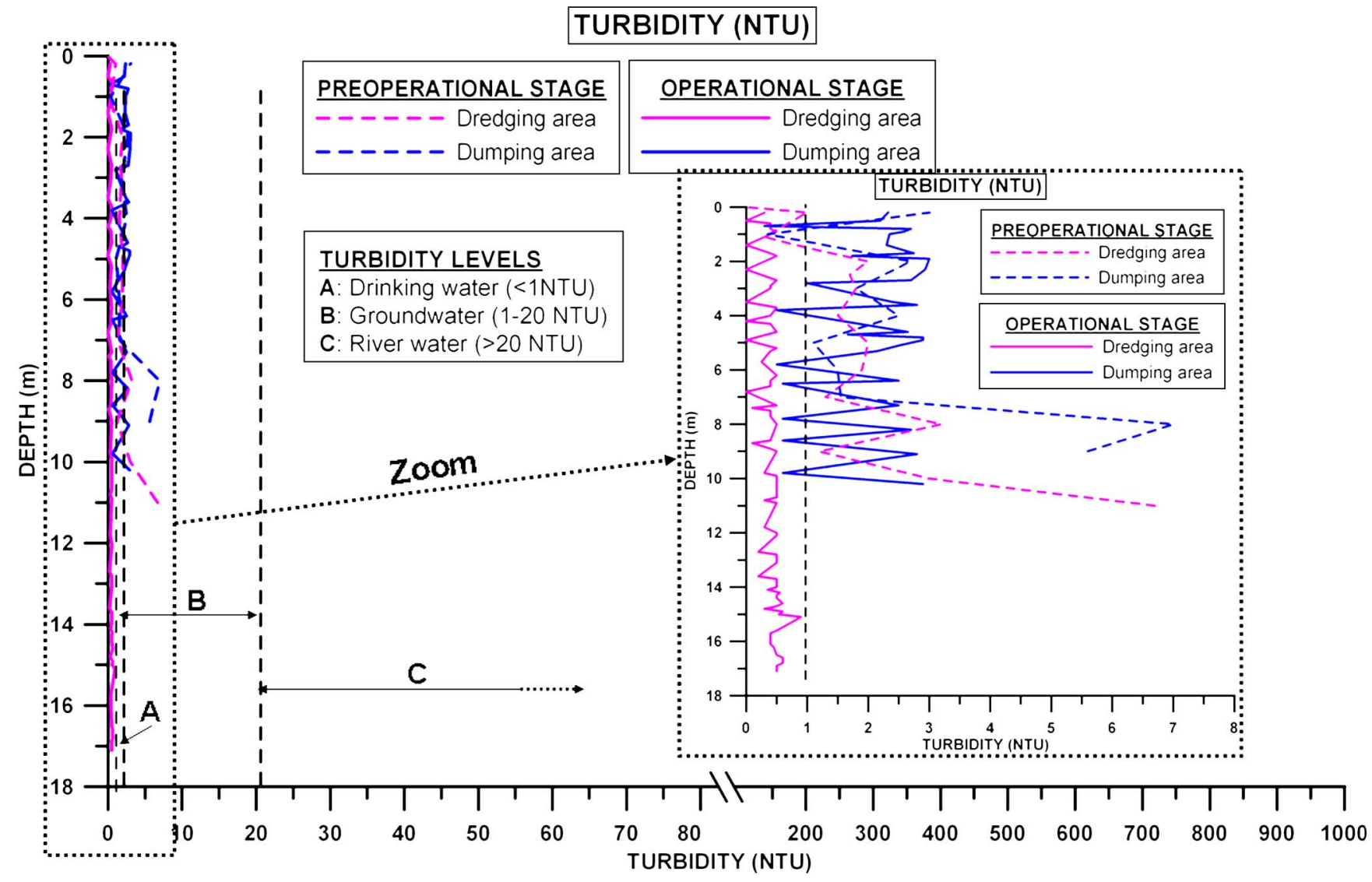

Fig. 6. Average turbidity values in preoperational and operational work stages

Table 3. Physicochemical Parameters Recorded at Dredging and Dumping Zones during Preoperational and Operational Campaigns

\begin{tabular}{|c|c|c|c|c|c|c|c|}
\hline & & & $\begin{array}{c}\text { Dissolved oxygen } \\
\text { saturation }(\%) \\
\end{array}$ & $\begin{array}{l}\text { Redox potential } \\
(\mathrm{mV})\end{array}$ & $\begin{array}{c}\text { Hydrogen } \\
\text { potential }(\mathrm{pH})\end{array}$ & Salinity $(\% o)$ & Temperature $\left({ }^{\circ} \mathrm{C}\right)$ \\
\hline \multirow[t]{8}{*}{ Dredging Zone } & \multirow[t]{4}{*}{ Preoperational } & Average & 111.35 & 325.09 & 8.37 & 36.81 & 17.11 \\
\hline & & SD & 1.97 & 14.56 & 0.19 & 0.25 & 0.30 \\
\hline & & Max. & 112.89 & 335.00 & 8.49 & 37.33 & 17.42 \\
\hline & & Min. & 109.25 & 315.00 & 8.21 & 36.55 & 16.90 \\
\hline & \multirow[t]{4}{*}{ Operational } & Average & 112.56 & 336.49 & 8.21 & 37.48 & 18.84 \\
\hline & & SD & 0.22 & 7.43 & 0.01 & 0.05 & 0.90 \\
\hline & & Max. & 113.10 & 349.05 & 8.24 & 37.58 & 21.20 \\
\hline & & Min. & 111.22 & 334.43 & 8.20 & 37.43 & 17.46 \\
\hline \multirow[t]{8}{*}{ Dumping Zone } & \multirow[t]{4}{*}{ Preoperational } & Average & 111.02 & 305.54 & 8.27 & 36.80 & 18.25 \\
\hline & & SD & 2.57 & 6.37 & 0.19 & 0.20 & 0.23 \\
\hline & & Max. & 114.90 & 310.00 & 8.39 & 37.25 & 18.80 \\
\hline & & Min. & 108.54 & 301.00 & 8.21 & 36.58 & 18.18 \\
\hline & \multirow[t]{4}{*}{ Operational } & Average & 112.66 & 356.04 & 8.25 & 37.52 & 19.79 \\
\hline & & SD & 0.87 & 1.39 & 0.02 & 0.05 & 0.38 \\
\hline & & Max. & 114.70 & 358.00 & 8.28 & 37.69 & 21.01 \\
\hline & & Min. & 111.30 & 352.00 & 8.19 & 37.40 & 19.08 \\
\hline
\end{tabular}

$\sim 336 \mathrm{mV}$ in the dredging zone and $356 \mathrm{mV}$ in the dumping zone, and the values were unvarying with depth.

The hydrogen potential $(\mathrm{pH})$ showed the most constant value in the entire water column and throughout all the campaigns. In the preoperational stage, the average $\mathrm{pH}$ values in the dredging and dumping areas were between 8.27 and $8.37( \pm 0.1)$; the average $\mathrm{pH}$ values were very similar for all operational campaigns $( \pm 0.04)$.
The salinity parameter was recorded in the dredging area during the preoperational stage, showing an average value of $36.81 \%$. Afterward, throughout the operational campaigns the average salinity value was $\sim 37.48 \%$ with an SD of $0.05 \%$. Around the dumping zone, the average salinity was $36.8 \%$ in the preoperational stage and $37.52 \%$ in the operational stage, with an SD of $0.05 \%$. 
Table 4. Suspended-Sediment Concentrations (mg/L). S: Surface; B: Bottom

\begin{tabular}{|c|c|c|c|c|c|c|c|c|c|}
\hline $\begin{array}{l}\mathrm{SSC}(\mathrm{mg} / \mathrm{L}) \\
\text { Stations }\end{array}$ & & Preoperational & Camp. 1 & Camp. 2 & Camp. 3 & Camp. 4 & Camp. 5 & Camp. 6 & Camp. 7 \\
\hline \multirow[t]{2}{*}{$\mathrm{T} 1$} & $\mathrm{~S}$ & $<2$ & $<2$ & $<2$ & $<2$ & 5 & $<2$ & $<2$ & 2 \\
\hline & B & 3 & $<2$ & $<2$ & 4 & $<2$ & $<2$ & $<2$ & $<2$ \\
\hline \multirow[t]{2}{*}{$\mathrm{T} 2$} & $\mathrm{~S}$ & $<2$ & $<2$ & $<2$ & 4 & 3 & $<2$ & $<2$ & $<2$ \\
\hline & B & $<2$ & 3 & $<2$ & $<2$ & 2 & $<2$ & $<2$ & $<2$ \\
\hline \multirow[t]{2}{*}{$\mathrm{T} 3$} & $\mathrm{~S}$ & $<2$ & $<2$ & $<2$ & 2 & $<2$ & $<2$ & $<2$ & 5 \\
\hline & B & $<2$ & $<2$ & $<2$ & $<2$ & 4 & $<2$ & $<2$ & $<2$ \\
\hline \multirow[t]{2}{*}{$\mathrm{T} 4$} & $\mathrm{~S}$ & $<2$ & $<2$ & $<2$ & $<2$ & $<2$ & $<2$ & $<2$ & 5 \\
\hline & B & $<2$ & $<2$ & $<2$ & $<2$ & 3 & $<2$ & $<2$ & $<2$ \\
\hline \multirow[t]{2}{*}{ E4 (2 m depth) } & $\mathrm{S}$ & $<2$ & 6 & $<2$ & 4 & $<2$ & $<2$ & $<2$ & $<2$ \\
\hline & B & $<2$ & 3 & 15 & 8 & 4 & $<2$ & $<2$ & 4 \\
\hline \multirow[t]{2}{*}{ E4 (5 m depth) } & S & 2 & $<2$ & $<2$ & $<2$ & 3 & $<2$ & $<2$ & 4 \\
\hline & B & 2 & $<2$ & $<2$ & 2 & 3 & $<2$ & $<2$ & 3 \\
\hline \multirow[t]{2}{*}{ E4 (10 m depth) } & $\mathrm{S}$ & $<2$ & 7 & 3 & $<2$ & 4 & $<2$ & $<2$ & $<2$ \\
\hline & B & 3 & $<2$ & $<2$ & $<2$ & 2 & $<2$ & $<2$ & 4 \\
\hline \multirow[t]{2}{*}{ E5 (2 m depth) } & $\mathrm{S}$ & 3 & $<2$ & $<2$ & $<2$ & $<2$ & $<2$ & $<2$ & 3 \\
\hline & B & $<2$ & 2 & 8 & $<2$ & $<2$ & $<2$ & $<2$ & 3 \\
\hline \multirow[t]{2}{*}{ E5 (5 m depth) } & $\mathrm{S}$ & $<2$ & $<2$ & $<2$ & $<2$ & $<2$ & $<2$ & $<2$ & 2 \\
\hline & B & $<2$ & $<2$ & 8 & 2 & $<2$ & $<2$ & 4 & $<2$ \\
\hline \multirow[t]{2}{*}{ E5 (10 m depth) } & $\mathrm{S}$ & $<2$ & 4 & $<2$ & $<2$ & 5 & $<2$ & $<2$ & 3 \\
\hline & B & $<2$ & $<2$ & $<2$ & $<2$ & $<2$ & $<2$ & $<2$ & 2 \\
\hline
\end{tabular}

For all stations, the maximum temperature was $17.42^{\circ} \mathrm{C}$ in the dredging zone and $18.80^{\circ} \mathrm{C}$ in the dumping zone on the sea surface during the preoperational stage. These values decreased with $10-\mathrm{m}$ depth in the order of $0.5^{\circ} \mathrm{C}$ approximately. After $10 \mathrm{~m}$, the temperature remained constant at approximately 16.90 and $18.18^{\circ} \mathrm{C}$, respectively. During the operational campaigns, the minimum temperature increased between 1 and $2^{\circ} \mathrm{C}$ on the sea surface in the dredging and dumping zones. Moreover, the temperature decrease with depth was generally more in the first zone than in the dumping zone: 1.5 and $0.5^{\circ} \mathrm{C}$, correspondingly. Nonetheless, the temperature decrease with depth was quite different at the same station depending on the day and deep ocean currents.

Table 4 shows the SSC (in $\mathrm{mg} / \mathrm{L}$ ) for all the stations in the dredging and dumping area in the natural stage of environment and all operational campaigns.

The SSC values obtained in Meca sandbank were very low $(<2 \mathrm{mg} / \mathrm{L})$, almost always below the detection limit. Significant values of SSC of approximately 8 and $15 \mathrm{mg} / \mathrm{L}$ were only observed at depths of 2 and $5 \mathrm{~m}$ at the E4 and E5 profiles in the dumping area near the nourished beach. These values were one order of magnitude more than natural concentrations. Generally in this case, natural values during the preoperational campaign were very similar to the operational values obtained during the nourishment activities. Sea conditions (current velocity and wave height) seem to have had an important weight on the collected data and on interpretation of the results (Table 2). In other cases (CSMW 2004), SSCs were equivalent to natural levels during storms. Poststorm monitoring of the swash, surf, and near-shore zones indicated that beach sediments at both recently filled and undisturbed beaches were equally susceptible to resuspension. In the swash, surf, and near-shore zones adjacent to the newly restored beaches, SSCs were generally comparable to or slightly higher than those at undisturbed reference beaches. Only in a few samples from the swash zone of the nourished beach were SSCs markedly elevated (Burlas et al. 2001). According to Barnard (1978), SSC rapidly decreases with increasing distance downstream or downcurrent from the

\section{TURBIDITY vs. SUSPENDED SEDIMENTS}

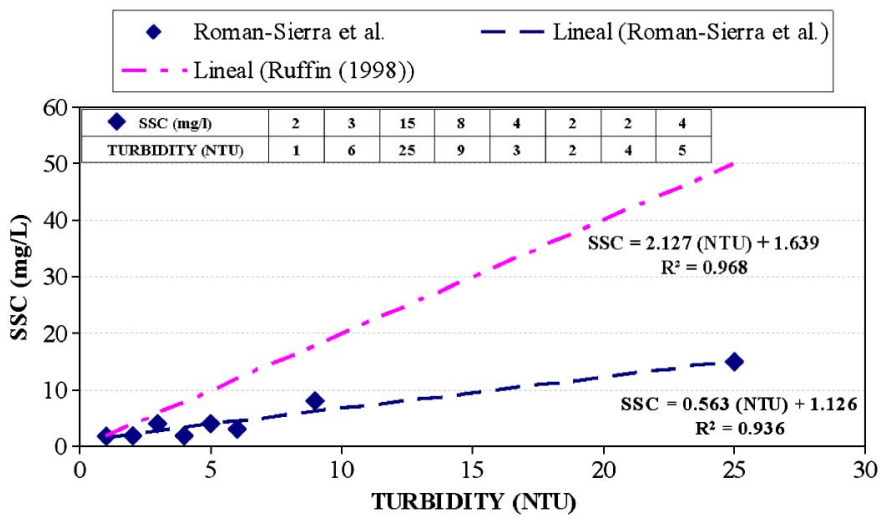

Fig. 7. Turbidity versus SSC in the dumping area for all work periods (data from Ruffin 1998)

discharge point and laterally away from the plume centerline because of settling and horizontal dispersion of the suspended solids.

According to Ruffin (1998), the values of turbidity $(x)$ and total suspended solids $(y)$ are closely correlated and can be described by the equation $y=2.127 x+1.639$, with a correlation coefficient of $R^{2}=0.968$. In this case, the SSCs were in concordance with the low turbidity values. The equation relating them is reflected by the linear regression $\mathrm{SSC}=0.563(\mathrm{NTU})+1.126$ in the scatter plot (Fig. 7), with a correlation coefficient of $R^{2}=0.936$. In contrast with Ruffin (1998), the elevated sand size and minimal percentage of silt and clay in the Meca sandbank sediment resulted in a much reduced concentration of suspended solids.

\section{Marine-Sediment Characterization}

Generally, during the preoperational campaign, the sediment characterization in the dredging and dumping zones showed average values of medium and coarse sands $\left(D_{50}=0.33 \mathrm{~mm}\right)$, with a 
Table 5. Parameters of Sediment Composition

\begin{tabular}{|c|c|c|c|c|c|}
\hline \multirow[b]{2}{*}{ Parameters } & \multirow[b]{2}{*}{ Stations } & \multicolumn{4}{|c|}{ Campaigns } \\
\hline & & Preoperational & $\begin{array}{l}3 \text { months } \\
\text { later }\end{array}$ & $\begin{array}{l}6 \text { months } \\
\text { later }\end{array}$ & $\begin{array}{l}12 \text { months } \\
\text { later }\end{array}$ \\
\hline \multirow{6}{*}{$\begin{array}{l}\text { Fine } \\
\text { content } \\
(\%)\end{array}$} & $\mathrm{T} 1$ & 0.86 & 1.43 & 1.80 & 1.80 \\
\hline & $\mathrm{T} 2$ & 1.01 & 1.43 & 0.60 & 3.10 \\
\hline & $\mathrm{T} 3$ & 0.71 & 1.27 & 1.00 & 2.00 \\
\hline & $\mathrm{T} 4$ & 1.43 & 1.78 & 1.10 & 3.10 \\
\hline & $\mathrm{E} 4$ & 0.07 & 1.64 & 0.90 & 3.00 \\
\hline & E5 & 1.81 & 1.46 & 0.80 & 2.10 \\
\hline \multirow{6}{*}{$\begin{array}{l}\text { SD } \\
\text { (sorting) }\end{array}$} & $\mathrm{T} 1$ & 0.61 & 0.98 & 0.80 & 1.48 \\
\hline & $\mathrm{T} 2$ & 0.55 & 1.29 & 0.52 & 0.62 \\
\hline & $\mathrm{T} 3$ & 0.71 & 1.28 & 1.34 & 1.32 \\
\hline & $\mathrm{T} 4$ & 0.98 & 1.37 & 0.96 & 1.15 \\
\hline & E4 & 0.31 & 0.64 & 1.03 & 0.85 \\
\hline & E5 & 0.74 & 1.20 & 1.12 & 0.97 \\
\hline \multirow{6}{*}{$\begin{array}{l}\text { Symmetry } \\
\text { (skewness) }\end{array}$} & $\mathrm{T} 1$ & 0.21 & -0.42 & -0.22 & -0.21 \\
\hline & $\mathrm{T} 2$ & 0.32 & -0.43 & -0.14 & -0.26 \\
\hline & $\mathrm{T} 3$ & 0.11 & -0.12 & -0.59 & -0.22 \\
\hline & $\mathrm{T} 4$ & -0.12 & -0.32 & -0.40 & -0.26 \\
\hline & E4 & 0.14 & -0.13 & -0.28 & -0.24 \\
\hline & E5 & 0.04 & -0.17 & -0.23 & -0.18 \\
\hline \multirow[t]{6}{*}{ D50 (mm) } & $\mathrm{T} 1$ & 0.31 & 0.23 & 0.26 & 0.45 \\
\hline & $\mathrm{T} 2$ & 0.34 & 0.29 & 0.20 & 0.22 \\
\hline & $\mathrm{T} 3$ & 0.34 & 0.44 & 0.24 & 0.39 \\
\hline & $\mathrm{T} 4$ & 0.23 & 0.35 & 0.24 & 0.23 \\
\hline & E4 & 0.19 & 0.19 & 0.23 & 0.18 \\
\hline & E5 & 0.59 & 0.45 & 0.33 & 0.22 \\
\hline \multirow{6}{*}{$\begin{array}{l}\text { Organic } \\
\text { matter }(\%)\end{array}$} & $\mathrm{T} 1$ & 0.80 & 0.80 & 0.90 & 1.60 \\
\hline & $\mathrm{T} 2$ & 0.80 & 0.90 & 1.00 & 0.70 \\
\hline & $\mathrm{T} 3$ & 0.60 & 1.50 & 0.90 & 1.00 \\
\hline & $\mathrm{T} 4$ & 0.80 & 1.70 & 0.90 & 0.90 \\
\hline & $\mathrm{E} 4$ & 1.30 & 1.40 & 1.20 & 1.20 \\
\hline & E5 & 1.50 & 1.50 & 0.80 & 1.50 \\
\hline
\end{tabular}

minimal composition of fine sands (approximately 0-2\%). The only exception was for the sediment present at station E5, where the $D_{50}$ was $0.59 \mathrm{~mm}$, with the modal value indicating coarse sands. The $D_{50}$ values were similar in the subsequent campaigns (approximately $0.29 \mathrm{~mm}$ ), indicating a medium sand size with a fine content between 0.6 and $3.1 \%$. There were a few samples (E5 and T3) with a $D_{50}$ of $0.45 \mathrm{~mm}$, but, in both cases, the sands had a medium size mode. All the values obtained for the different parameters and campaigns can be observed in Table 5. For an easy comparison of borrow sand and native beach sand, selected plots of size distribution are shown in Fig. 8.

In the preoperational campaign, the SD obtained (the sorting index) indicated that the sediments of the E4 station were well classified. The remaining sediment samples were moderately well classified except for the E5, T3, and T4 samples, which were moderately sorted (USACE 2008). In the following postoperational campaigns, the sorting indexes indicated that the sediment samples T3, T4, and E5 were moderately sorted. Samples T1 and T2 were moderately well sorted, and finally, sample E4 was very well sorted.

The skewness index obtained in the preoperational stage indicated a wide range of symmetry values for the sediments present in different stations. Sediments from station E5 followed a symmetrical distribution, whereas the T1, T3, and E4 samples had a

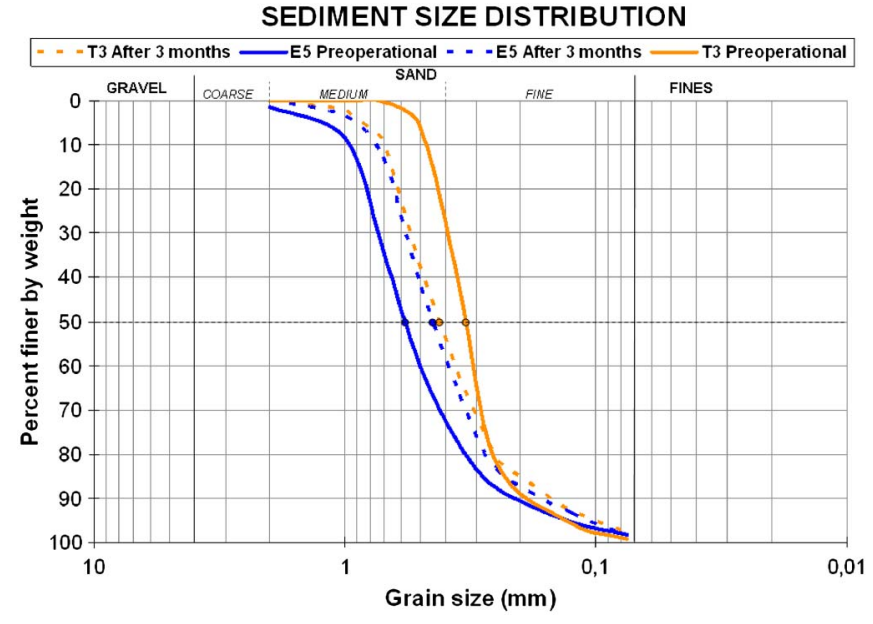

Fig. 8. Sediment distribution by using semilog paper: Stations T3 and E5 (during the preoperational stage and 3 months after works)

fine-skewed distribution. This indicated that there was a tailing out toward the fine sediments (USACE 2008). Finally, the sediment of the T2 sample showed a very fine-skewed distribution and T4 showed a very coarse-skewed distribution (indicating more outliers in the coarser sediments). In the postoperational campaigns, the averaged skewness index indicated that generally all stations showed a coarse-skewed distribution. The T3 sample showed a very coarse-skewed distribution.

The proportion of oxidizable organic matter in the sediment was very low, with an average value of $0.97 \%$ and a maximum value of $1.50 \%$. During the posterior monitoring campaigns, the average value of organic matter was $1.13 \%$ with a maximum value of $1.70 \%$.

The content of fine organic matter was very low for all stations, with an average value of $0.98 \%$ and a maximum value of $1.81 \%$ in the preoperational stage. During the next campaigns, the organic matter had an average value of $1.68 \%$ and a maximum value of $3.10 \%$ at the $\mathrm{T} 2$ and $\mathrm{T} 4$ stations 12 months after the dredging activities.

The percentage of sediment remaining in suspension with time depends predominantly on the relative proportions of each grainsize fraction in the local bed sediments (Black and Parry 1999). The fine particles in a plume are advected by the current and also undergo settling. Coarser sediments will be transported a lesser distance away from the point of discharge (CSMW 2004). Noncohesive sediments, or those greater than sand size $(>2 \mathrm{~mm})$, are generally considered to fall to the seabed immediately (Hitchcock et al. 1999). The duration of turbidity in water is largely based on the falling velocity of the sediment particles. Falling velocity depends on size, shape, density of the particles, the fluid density, viscosity, and several other parameters. When a particle falls through water, it accelerates until it reaches its falling or settling velocity. This is the terminal velocity that a particle reaches when the (retarding) drag force on the particle just equals the (downward) gravitational force (USACE 2008).

In the case of the Meca sandbank and Palmar Beach, the medium-sized sand $(0.33-0.45 \mathrm{~mm})$ and marine conditions in the area suggest a dispersion time of approximately 9 min within a surface plume of $400 \mathrm{~m}$. In this sense, according to Muñoz-Perez et al. (1999), the quick disappearance of coarse and very fine sand is related to the response of these fractions to wave-induced current effects. According to Vanoni (1975), the theoretical falling velocity of sediment particles composed primarily of quartz (i.e., medium-sized sand approximately $0.33 \mathrm{~mm}$ ) is approximately 
Table 6. Average Ecological Indexes Monitored at All Zones for One Year

\begin{tabular}{|c|c|c|c|c|c|c|}
\hline \multirow[b]{2}{*}{ Stations } & \multirow[b]{2}{*}{ Campaigns } & \multicolumn{5}{|c|}{ Average Ecological Indexes } \\
\hline & & $\mathrm{N}$ of species $(\mathrm{S})$ & Diversity $\left(\mathrm{H}^{\prime}\right)$ & Equitability $\left(\mathrm{J}^{\prime}\right)$ & Dominance (D) & Complexity ( $\mathrm{N}$ of phylum) \\
\hline \multirow[t]{4}{*}{ T1 zone } & Preoperational & 3.00 & 1.10 & 1.00 & 0.00 & 3.00 \\
\hline & 3 months later & 3.00 & 0.90 & 0.80 & 0.40 & 2.00 \\
\hline & 6 months later & 4.00 & 1.30 & 1.00 & 0.10 & 4.00 \\
\hline & 12 months later & 5.00 & 1.20 & 0.70 & 0.40 & 4.00 \\
\hline \multirow[t]{4}{*}{$\mathrm{T} 2$ zone } & Preoperational & 1.00 & 0.00 & 0.00 & 1.00 & 1.00 \\
\hline & 3 months later & 3.00 & 1.00 & 0.90 & 0.30 & 2.00 \\
\hline & 6 months later & 2.00 & 0.60 & 0.80 & 0.50 & 2.00 \\
\hline & 12 months later & 6.00 & 1.50 & 0.90 & 0.20 & 2.00 \\
\hline \multirow[t]{4}{*}{ T3 zone } & Preoperational & 3.00 & 1.00 & 0.90 & 0.30 & 2.00 \\
\hline & 3 months later & 0.00 & 0.00 & - & - & 0.00 \\
\hline & 6 months later & 2.00 & 0.70 & 1.00 & 0.00 & 1.00 \\
\hline & 12 months later & 7.00 & 1.60 & 0.80 & 0.20 & 3.00 \\
\hline \multirow[t]{4}{*}{ T4 zone } & Preoperational & 3.00 & 1.10 & 1.00 & 0.20 & 1.00 \\
\hline & 3 months later & 0.00 & 0.00 & - & - & 0.00 \\
\hline & 6 months later & 6.00 & 1.60 & 0.90 & 0.20 & 1.00 \\
\hline & 12 months later & 6.00 & 1.70 & 0.90 & 0.10 & 2.00 \\
\hline \multirow[t]{4}{*}{ E4 zone } & Preoperational & 3.00 & 1.00 & 0.90 & 0.30 & 2.00 \\
\hline & 3 months later & 8.00 & 1.70 & 0.80 & 0.20 & 3.00 \\
\hline & 6 months later & 3.00 & 0.80 & 0.70 & 0.50 & 2.00 \\
\hline & 12 months later & 3.00 & 0.70 & 0.70 & 0.60 & 2.00 \\
\hline \multirow[t]{4}{*}{ E5 zone } & Preoperational & 2.00 & 0.70 & 1.00 & 0.40 & 1.00 \\
\hline & 3 months later & 3.00 & 0.60 & 0.60 & 0.60 & 2.00 \\
\hline & 6 months later & 6.00 & 1.40 & 0.80 & 0.30 & 3.00 \\
\hline & 12 months later & 4.00 & 1.10 & 0.80 & 0.30 & 3.00 \\
\hline
\end{tabular}

$3.8 \mathrm{~cm} / \mathrm{s}$ in water. The falling time of the sediment in the Meca sandbank, at $18-\mathrm{m}$ depth, was approximately $8 \mathrm{~min}$ and $30 \mathrm{~s}$. These values are in agreement with the values obtained in the turbidity temporal and space studies.

\section{Benthic-Community Characterization}

This investigation monitored various ecological indexes in the dredging and dumping zones to determine the ecological environmental effects (differentiating the sedimentary and rocky zones). The results obtained from submarine biosphere monitoring are shown in Table 6.

In the preoperational stage, the values obtained for the number of species, diversity, and complexity are very low (a range of 1 to 5) compared to how these indexes would be for this kind of marine environment (Gonzalez et al. 2008). The submerged Meca sandbank always displays harsh dynamic conditions for benthic communities because of its mobile and unconsolidated nature. These features account for the natural low biological diversity of the ocean floor in this area (Ministry of Environment 2003). The results obtained in the dumping area for the subsequent campaigns, although low, can be considered within the normal range for all campaigns because a decrease was not observed. Moreover, an absence of organisms was observed in the dredging area at T3 and T4 zones after 3 months. This decrease was expected after the extraction because of the removal of the surface layer of sand inhabited by the biota. Nevertheless, the values obtained in the extraction area exceeded those obtained in the preoperational stage. This suggests, in biological terms, a complete recovery of the biological community at all stations after 6 months.

Sedimentary area results are as follows:

- Communities located on natural sedimentary substrata showed a low degree of development in both dredging and dumping areas.
- A minimum decrease of ecological richness was identified in the dredging area after the sand extraction.

- A complete recuperation of the dredging area was observed 6 months after the dredging.

- In the dumping area, disturbances in the benthonic communities during the operations were considered minimal, recovering biological equilibrium 1 year after the operation.

Rocky-area results are as follows:

- A medium degree of development was observed in the preoperational states of the biological communities.

- A decrease in ecological fragility was identified in the coastal areas, 6 months after the operations. This decrease was probably because of the disappearance of certain algal species during the summer season (Raffaelli and Hawkins 1999).

- The ecological indexes were similar to those obtained during the preoperational state at all the monitoring stations 1 year after the operations. This finding suggests that the disturbances produced in the rocky-area biological communities were assimilated by the marine environment during this period and their ecological states were completely recovered.

\section{Conclusions}

The Spanish Coastal Authority recently completed one of the largest beach-nourishment projects of the past decade, placing $595,000 \mathrm{~m}^{3}$ of medium-sized sand sourced from the Meca sandbank along $4 \mathrm{~km}$ of the high-energy El Palmar Beach (southwest Cadiz). Dredging and dumping operations were monitored in this study following a new research line. The methods were aimed at assessing several physical and chemical parameters before, during, and after the operations at the various dredging and dumping areas. 
Thus, turbidity, SSC, salinity, dissolved oxygen, $\mathrm{pH}$, temperature, redox potential, sediment quality, and ecological variables were recorded to determine the environmental effects.

After a spatial and temporal turbidity study, it was concluded that turbidity decreased with time, reaching natural conditions approximately $9 \mathrm{~min}$ after the operations. Turbidity values became normalized at a spatial scale between 250 and $400 \mathrm{~m}$ away from the dredging zone. These results evidenced that dredging activities resulted in a minimal effect on water quality. Because of the low turbidity values recorded at all fixed stations, the turbidity plume had no significant temporal or spatial dispersion. In this sense, sea conditions (current velocity and wave height) seem to have important effects on data collection and the interpretation of results.

During the dredging and nourishment operations, SSCs in the surf zone ranged from $<2$ to $15 \mathrm{mg} / \mathrm{L}$; they were also analogous to those collected in the preoperational phase. In addition, salinity, $\mathrm{pH}$, dissolved oxygen, temperature, and redox potential showed no abnormal variations from those found in normal conditions.

Dredging effects on aquatic flora were determined to be reversible. After the operations, ecological indexes were similar to those obtained during the preoperational state for all the monitoring stations, suggesting minimal disturbances to the sedimentary and rocky biological communities. These ecosystems completely recovered their ecological states 1 year and 6 months after the operations for the sedimentary and rocky biological communities, respectively.

As a general conclusion, the dredging and discharge of sand did not increase the overall turbidity of the waters and sediments that were studied. Moreover, these works did not worsen the quality of the hydrological and ecological environment. The high erosion rates identified on this coastline and the minimal environmental effect resulting from the dredging activities conducted during this research, appear to justify the use of dredging activities for beachnourishment purposes. As a result, useful social benefits have been derived from its use.

\section{Acknowledgments}

The authors wish to thank the Coastal General Directorate of the Spanish Ministry of Environment and Tecnoambiente, S.L., both in Cadiz, for their support throughout the development of this research.

\section{References}

Anfuso, G., and Gracia, F. J. (2005). "Morphodynamic characteristics and short-term evolution of a coastal sector in SW Spain: Implications for coastal erosion management." J. Coastal Res., 21(6), 1139-1153.

ASTM. (1992). "Standard test methods for particle size analysis of soils." 04.08, Soil and Rock (1), D420-D4914, Philadelphia.

Barnard, W. D. (1978). "Prediction and control of dredged material dispersion around dredging and open-water pipeline disposal operations." Technical Rep., U.S. Army Corps of Engineers Waterways Experiment Station, Vicksburg, MS, 78-113.

Black, K. P., and Parry, G. D. (1994). "Sediment transport rates and sediment disturbance due to scallop dredging in Port Phillip Bay." Mem. Queensl. Mus., 36(2), 327-341.

Black, K. P., and Parry, G. D. (1999). "Entrainment, dispersal, and settlement of scallop dredge sediment plumes: Field measurements and numerical modelling." Can. J. Fish. Aquat. Sci., 56(12), 2271-2281.

Brenon, I., and Le Hir, P. (1999). "Modelling the turbidity maximum in the Seine Estuary (France): Identification of formation processes." Estuarine, Coastal Shelf Sci., 49(4), 525-544.

Burlas, M., Ray, G., and Clarke, D. (2001). The New York District's biological monitoring program for the Atlantic Coast of New Jersey,
Asbury Park to Manasquan Section Beach Erosion Control Project, U.S. Army Corps of Engineers Waterways Experiment Station, Vicksburg, MS.

California Coastal Sediment Management Workgroup (CSMW). (2004). California Resources Agency and U. S. Army Corps of Engineers (South Pacific Division). 〈http://www.spd.usace.army.mil/csmwonline/ index.htm $\rangle$.

Dabrio, C. J., et al. (2000). "Depositional history of estuarine infill during the last postglacial transgression (Gulf of Cadiz, Southern Spain)." Mar. Geol., 162(2-4), 381-404.

Drucker, B. S., Waskes, W., and Byrnes, M. R. (2004). “The, U. S. Minerals Management Service outer continental shelf sand and gravel program: Environmental studies to assess the potential effects of offshore dredging operations in federal waters." J. Coastal Res., 20(1), 1-5.

Giardino, A., Ibrahim, E., Adam, S., Toorman, E. A., and Monbaliu, J. (2009). "Hydrodynamics and cohesive sediment transport in the Ijzer estuary, Belgium: Case study." J. Waterway, Port, Coastal, Ocean Eng., 135(4), 176-184.

Gomez-Pina, G., Fages, L., Ramirez, J. L., Muñoz-Perez, J. J., and Enriquez, J. (2006). "A critical review of beach restoration projects in the northern coast of Cadiz (Spain) after thirteen years." 30th Int. Conf. on Costal Engineering, ASCE, Reston, VA, 4167-4178.

Gonzalez, A. R., et al. (2008). "Community structure of caprellids (Crustacea: Amphipoda: Caprellidae) on seagrasses from southern Spain.” Helgol. Mar. Res., 62(3), 189-199.

Goodwin, C., and Michaelis, D. (1984). "Appearance and water quality of turbidity plumes produced by dredging in Tampa Bay, Florida, U. S." Geological Survey Water-Supply Paper 2192, U.S. Geological Survey, Reston, VA.

Herbich, J. B. (1992). Handbook of dredging engineering, McGraw-Hill Professional, New York, 992.

Hitchcock, D. R., and Bell, S. (2004). "Physical impacts of marine aggregate dredging on seabed resources in coastal deposits." J. Coastal Res., 20(1), 101-114.

Hitchcock, D. R., Newell, R. C., and Seiderer, L. J. (1999). "Marine aggregate mining benthic and surface plume study." Rep. for the U.S. Department of the Interior, Minerals Management Service, Coastline Surveys Ltd, Gloucestershire, UK.

Iannuzzi, T. J., Weinstein, M. P., Sellner, K. G., and Barrett, J. C. (1996). "Habitat disturbance and marina development: An assessment of ecological effects. Changes in primary production due to dredging and marina construction.” Estuaries, 19(2), 257-271.

Kennedy, A. B., Slatton, K. C., Starek, M., Kampa, K., and Cho, H-C. (2010). "Hurricane response of nearshore borrow pits from airborne bathymetric lidar." J. Waterway, Port, Coastal, Ocean Eng., 136(1), 46-58.

Lewis, M. A., Weber, D. E., Stanley, R. S., and Moore, J. C. (2001). "Dredging impact on an urbanized Florida bayou: Effects on benthos and algal-periphyton." Environ. Pollut., 115(2), 161-171.

Lloyd, M., and Ghelardi, R. J. (1964). "A table for calculating the 'equitability' component of species diversity." J. Anim. Ecol., 33(2), 217-225.

Long, B. G., Dennis, D. M., Skewes, T. D., and Poiner, I. R. (1996). "Detecting an environmental impact of dredging on seagrass beds with a BACIR sampling design.” Aquat. Bot., 53(3-4), 235-243.

Lyngby, J. E., and Mortensen, S. M. (1996). "Effects of dredging activities on growth of laminaria saccharina." Mar. Ecol., 17(1-3), 345-354.

Ministry of Environment. (2003). "Environmental impact study: Use of Meca sandbank to Cadiz beach nourishment." Resolution of the General Secretariat of the Environment, BOE 108, 17266-17270 (in Spanish).

Muñoz-Perez, J. J. (2008). "Artificial reefs to improve and protect fishing grounds.” Recent Pat. Eng., 2(2), 80-86.

Muñoz-Perez, J. J., Gutiérrez-Mas, J. M., Moreno, J., Español, L., Moreno, L., and Bernabeu, A. (2003). "Portable meter system for dry weight control in dredging hoppers." J. Waterway, Port, Coastal, Ocean Eng., 129(2), 79-85.

Muñoz-Perez, J. J., Gutiérrez-Mas, J. M., Parrado, J. M., and Moreno, L. (1999). "Sediment transport velocity by tracer experiment at Regla Beach (Spain)." J. Waterway, Port, Coastal, Ocean Eng., 125(6), 332-335. 
Muñoz-Perez, J. J., Lopez, B., Gutierrez-Mas, J. M., Moreno, L., and Cuena, G. J. (2001). "Cost of beach maintenance in the Gulf of Cadiz (SW Spain)." Coastal Eng., 42(2), 143-153.

Muñoz-Perez, J. J., Navarro, M., Roman-Sierra, J., Tejedor, B., Rodriguez, I., and Gomez-Pina, G. (2009). "Long-term evolution of a transgressive migrating dune using reconstruction of the EOF method." Geomorphology, 112(1-2), 167-177.

Onuf, C. P. (1994). "Seagrasses, dredging and light in Laguna Madre, Texas, U. S. A.” Estuarine, Coastal Shelf Sci., 39(1), 75-91.

OSPAR Convention for the Protection of the Marine Environment of the North-East Atlantic. (2003). Guidelines for the management of marine sediment extraction, International Council for the Exploration of the Sea (ICES), Copehagen, Denmark.

Parr, T., Diener, D., and Lacy, S. (1978). "Effects of beach replenishment on the nearshore sand fauna at Imperial Beach, California." Miscellaneous Rep. 78-4, U.S. Army Corps of Engineers, Coastal Engineering Research Center, Fort Belvoir, VA.

Pennekamp, J. G. S., et al. (1996). "Turbidity caused by dredging; Viewed in perspective." Int. J. Public Works, Ports, Waterw. Dev., 64, 10-17.

Raffaelli, D., and Hawkins, S. (1999). Intertidal ecology, Chapman \& Hall, London.

Robinson, J. E., Newell, R. C., Seiderer, L. J., and Simpson, N. M. (2005). "Impacts of aggregate dredging on sediment composition and associated benthic fauna at an offshore dredge site in the southern North Sea." Mar. Environ. Res., 60(1), 51-68.

Ruffin, K. K. (1998). "The persistence of anthropogenic turbidity plumes in a shallow water estuary." Estuarine, Coastal Shelf Sci., 47(5), 579-592.

Spanish Port System. (2008). "Oceanography and meteorology data base." 〈www.puertos.es〉.

Teeter, A. M. (1988). "Clamshell-dredge overflow plume evaluation." Proc., 21st Annual Dredging Seminar, Wilmington, NC, 94-110.
UNE—EN. (1999). "General requirements for the competence of testing and calibration laboratories." ISO/IEC 17025, International Organization for Standardization.

U.S. Army Corps of Engineers (USACE). (2008). "Coastal sediment properties." Coastal Engineering Manual-Part III, EM 1110-2-1100.

U.S. Army Corps of Engineers (USACE) and U.S. Environmental Protection Agency (USEPA). (1992). Evaluating environmental effects of dredged material management alternatives: Technical framework, Washington, DC.

Vanoni, V. A. (1975). "Sedimentation engineering.” Manual No. 54, ASCE, Reston, VA.

Versar, I. (2004). "Year two recovery from impacts of beach nourishment on surf zone and nearshore fish and benthic resources on Bald Head Island, Caswell Beach, Oak Island, and Holden Beach, North Carolina." U.S. Army Corp of Engineers (USACE), Wilmington District.

Wilber, D. H., and Clarke, D. G. (2001). "Biological effects of suspended sediments: A review of suspended sediment impacts on fish and shellfish with relation to dredging activities in estuaries." North Am. J. Fisheries Manage., 21(4), 855-875.

Winterwerp, J. C. (2002). "Near-field behaviour of dredging spill in shallow water." J. Waterway, Port, Coastal, Ocean Eng., 128(2), 96-98.

Wolanski, E., Gibbs, R., Didd, P., and Mehta, A. (1992). "Settling of ocean dumped dredging material Townsville, Australia." Estuarine, Coastal Shelf Sci., 35(5), 473-489.

Work, P. A., Fehrenbacher, F., and Voulgaris, G. (2004). "Nearshore impacts of dredging for beach nourishment." J. Waterway, Port, Coastal, Ocean Eng., 130(6), 303-311.

World Health Organization (WHO). (1998). "Drinking water directive." Council Directive 98/83/EC of 3 November 1998 on the quality of water intended for human consumption, Environment European Commission. 
Copyright of Journal of Waterway, Port, Coastal \& Ocean Engineering is the property of American Society of Civil Engineers and its content may not be copied or emailed to multiple sites or posted to a listserv without the copyright holder's express written permission. However, users may print, download, or email articles for individual use. 